Tropical Journal of Pharmaceutical Research April 2017; 16 (4): 955-962

ISSN: $1596-5996$ (print); 1596-9827 (electronic)

(C) Pharmacotherapy Group, Faculty of Pharmacy, University of Benin, Benin City, 300001 Nigeria.

All rights reserved.

Available online at http://www.tjpr.org

Original Research Article

http://dx.doi.org/10.4314/tjpr.v16i4.30

\title{
Knowledge and perception of breast cancer and its treatment among Malaysian women: Role of religion
}

\author{
Noraida Mohamed Shah*, Billy Lim Tzyy Nan, Nies Yong Hui, Farida Hanim \\ Islahudin and Ernieda Mhd Hatah \\ Faculty of Pharmacy, Universiti Kebangsaan Malaysia, Kuala Lumpur, Malaysia
}

${ }^{*}$ For correspondence: Email: noraida_mshah@ukm.edu.my; Tel: +603-92898038; Fax: +603-26983271

Received: 10 September 2016

Revised accepted: 8 March 2017

\begin{abstract}
Purpose: To investigate the association between religiosity, perceptions, and knowledge of breast cancer and its treatment among women in Malaysia.

Methods: Knowledge and perceptions of breast cancer and its treatment were determined via a questionnaire adapted from previous studies. The Duke Religion Index was used to measure participants' religiosity. The questionnaires were distributed among women in public areas in Kuala Lumpur.

Results: A total of 384 women participated in this study. Non-organisational religious activity (NORA; $r$ $=-0.113, p<0.05)$ and intrinsic religiosity $(I R ; r=-0.183, p<0.01)$ were significantly negatively correlated with knowledge of breast cancer. NORA $(r=0.115, p<0.05)$ and $\operatorname{IR}(r=0.229, p<0.01)$ were positively, significantly correlated with the perception that patients who underwent treatment for breast cancer can enjoy good quality of life. There was also a significant positive correlation between NORA $(r=0.175, p<0.05)$ and IR $(r=0.249, p<0.01)$ on the statement that spiritual support improves treatment for breast cancer. IR was the only subscale positively, significantly associated with the perception of choosing breast-conserving surgery as a primary treatment choice $(r=-0.111, p<0.05)$ and dietary therapies $(r=0.126, p<0.05)$ or acupuncture $(r=0.120, p<0.05)$ as alternative treatments for breast cancer.

Conclusion: Religiosity should be considered in improving women's knowledge and perceptions of breast cancer and its treatment.
\end{abstract}

Keywords: Breast cancer, Knowledge, Perceptions, Religiosity

Tropical Journal of Pharmaceutical Research is indexed by Science Citation Index (SciSearch), Scopus, International Pharmaceutical Abstract, Chemical Abstracts, Embase, Index Copernicus, EBSCO, African Index Medicus, JournalSeek, Journal Citation Reports/Science Edition, Directory of Open Access Journals (DOAJ), African Journal Online, Bioline International, Open-J-Gate and Pharmacy Abstracts

\section{INTRODUCTION}

The incidence rate of breast cancer is the second highest across all types of cancers and ranks as the fifth cause of cancer deaths overall [1]. Breast cancer has an age-standardized incidence rate of 38.7 for every 100,000 people in Malaysia, which is higher than the average incidence for the rest of South-Eastern Asia at 34.8 for every 100,000 people [2].
Malaysia, with Thailand, is encountering increased breast cancer mortality rates, in contrast to other Asia-Pacific countries. Malaysia recorded an increment of $6 \%$ per year between 1997 and 2008, practically identical to the increment in Thailand, reported as $7 \%$ per year from 2000 to 2006 [2]. However, the problem of late diagnosis in Malaysia is significant; approximately $50-60 \%$ of women are typically in stages 3 or 4 at the first diagnosis of breast cancer. It is believed that several factors have 
contributed to delays in presentation with breast cancer, such as strong beliefs in traditional medicine, negative sociocultural perceptions of breast cancer, poverty, lack of education, fear, and denial [3].

According to the Handbook of Religion and Health [4], the associations of religiosity with health behaviours and mental and physical health have been studied. Religiosity is the degree of religious activity among those who are religious and includes attendance at a place of worship, religious group participation, faith in a god, prayer, reading of scriptures, and religious attitudes [5]. Religiosity has been mostly evaluated for its effect on quality of life, wellbeing, and perceptions of illness in cancer research [6]. Research has reported a significant influence of religiosity on health outcomes for conditions such as kidney disease and depression $[7,8]$.

Studies have been conducted in Malaysia on knowledge of breast cancer and the practice of breast self-examination [9], awareness [10], knowledge, and perceptions of breast cancer among women [11]. However, none have investigated how religion affects knowledge and perceptions of breast cancer.

As Malaysia is a multi-racial country with various religious beliefs, religiosity may be an important factor associated with knowledge and perceptions of breast cancer and its treatment among Malaysian women.

\section{METHODS}

\section{Study design}

A cross-sectional study was conducted from August to December 2015 on the associations between religiosity and knowledge and perceptions of breast cancer and its treatment among women. This study commenced following ethical approval by the Research Ethics Committee of the authors' academic institution (UKM 1.5.3.5/244/NF-051-15) and conducted according to the principles expressed in the Declaration of Helsinki [12]. Three hundred and eighty-four (384) women from Kuala Lumpur participated in the study. Women aged $\geq 18$ years with no personal or family history of breast cancer, who could read and understand the questionnaires were included in this study. However, women with cognitive problems (e.g. Alzheimer's disease, mental retardation, or dementia), a psychiatric illness, or poor understanding of the language used were excluded.

\section{Questionnaire survey}

A set of questionnaires in both English and Malay languages were distributed to women at public areas (e.g. shopping malls, recreational parks, and bus terminals), who met the inclusion/exclusion criteria. The target sample was identified through convenience sampling. The self-administered questionnaires were divided into four sections, viz, A, B, C, and D. Section $A$ included socio-demographic data such as age, sex, ethics, religion, income, marital status, education level, and employment status; Section B consisted of the Duke University Religion Index (DUREL), used with permission to measure the religiosity of women in the general public [13]. DUREL consists of five questions that are related to three subscales pertaining to religious activities, namely, organisational religious activity (ORA), non-organisational religious activity (NORA), and intrinsic religiosity (IR). Each of these subscales had to be analysed independently. Responses for both ORA and NORA ranged from scores of 1 (rarely or never) to 6 (more than once a week). The IR scale had three questions, with each response ranging from a score of 1 (definitely not true) to 6 (definitely true of me). A Malay version of DUREL had been translated and validated for use by Nurashikin et al [14].

Questions about knowledge and perceptions of breast cancer were presented in sections $C$ and $D$, respectively. The questions in both sections were adapted from an instrument used in a study by Hadi et al, from whom permission was obtained [11]. For section $\mathrm{C}$, the questions were divided into three parts: four questions on general knowledge, ten questions on knowledge of risk factors, and eight questions on knowledge of symptoms and screening. A rank score (yes/no/not sure) was applied to knowledge items. The scoring method was ' 1 ' for correct answers and '0' for incorrect or unsure answers. The total score on knowledge (general knowledge + risk factor + symptoms and screening) was calculated and used for analysis. Knowledge was categorised based on the total score obtained, as shown in Table 1 below.

Table 1: Knowledge categorization

\begin{tabular}{ll}
\hline Total score & Knowledge \\
\hline$<8$ & Very poor \\
$8-11$ & Poor \\
$12-16$ & Moderate \\
$17-20$ & Good \\
$>20$ & Very good \\
\hline
\end{tabular}


For section $D$, the questions were mainly on perceptions of breast cancer and its treatment. It incorporated nine questions associated with outcomes and treatment choices for breast cancer.

A Likert-type scale was used to evaluate the perceptions of women in the general public. Scores of '5', '4', '3', '2', and '1' were assigned to 'strongly agree', 'agree', 'neutral', 'disagree', and 'strongly disagree', respectively. Reverse coding was used for negative statements. The questionnaire was pretested (piloted) prior to full commencement of the study to ensure its suitability for the studied population.

\section{Statistical analysis}

The IBM Statistical Package for the Social Science $\left(\right.$ SPSS $^{\circledR}$ ) version 22.0 was used for statistical analysis. Continuous data were analysed descriptively through means and standard deviations for normally distributed data (i.e., parametric), or medians and interquartile ranges if the data were not normally distributed (i.e. non-parametric); categorical data were expressed in frequencies and percentages. Scores on each part relating to knowledge of breast cancer (general knowledge, risk factors, symptoms, and screening) and overall scores were summed up to obtain the median knowledge score.

Non-parametric tests such as the Kruskal-Wallis were used to evaluate the knowledge score of women in the general public based on sociodemographic variables. Post-hoc tests determined which pairwise groups showed significance. Spearman's rho correlation was used to determine the association between religiosity and knowledge of breast cancer, as well as religiosity and perceptions of breast cancer. All analyses were set as two-tailed with a confidence interval of $95 \%$ and a p-value less than 0.05 was considered statistically significant.

\section{RESULTS}

\section{Socio-demographic characteristics and religiosity among respondents}

Table 2 provides the details about respondents' socio-demographic data. The mean age of the respondents was $31.9 \pm 11.68$ years and half of the total respondents were Malay (194, $50.5 \%$ ); hence, Islam (186, $48.4 \%$ ) was the dominant religion among them. In addition, more than half of the respondents were single $(214,55.7 \%)$ and had tertiary education (251, $65.4 \%)$.
Table 2: Respondents' socio-demographic data

\begin{tabular}{|c|c|}
\hline Variable & $\begin{array}{l}\text { Number (\%) } \\
\mathrm{N}=384\end{array}$ \\
\hline \multicolumn{2}{|l|}{ Age (years) } \\
\hline \multicolumn{2}{|l|}{ Mean: $31.9 \pm 11.68$} \\
\hline $18-24$ & $138(35.9)$ \\
\hline $25-34$ & $124(32.3)$ \\
\hline $35-44$ & $69(18.0)$ \\
\hline $45-54$ & $34(8.9)$ \\
\hline 55 and above & $19(4.9)$ \\
\hline \multicolumn{2}{|l|}{ Race } \\
\hline Malay & $194(50.5)$ \\
\hline Chinese & $140(36.5)$ \\
\hline Indian & $44(11.5)^{\prime}$ \\
\hline Others & $6(1.6)$ \\
\hline \multicolumn{2}{|l|}{ Religion } \\
\hline Islam & $186(48.4)$ \\
\hline Buddhism & $104(27.1)$ \\
\hline Christian & $49(12.8)$ \\
\hline Hinduism & 39 (10.2) \\
\hline Others & $6(1.6)$ \\
\hline \multicolumn{2}{|l|}{ Marital status } \\
\hline Single & $214(55.7)$ \\
\hline Married & $163(42.4)$ \\
\hline Divorced & $1(0.3)$ \\
\hline Widow/widower & $6(1.6)$ \\
\hline \multicolumn{2}{|l|}{ Educational level } \\
\hline Primary & $11(2.9)$ \\
\hline Secondary & $116(30.2)$ \\
\hline Tertiary & $251(65.4)$ \\
\hline (College/University) & $6(1.6)$ \\
\hline None & \\
\hline \multicolumn{2}{|l|}{ Employment status } \\
\hline Government & $49(12.8)$ \\
\hline Private & $147(38.3)$ \\
\hline Unemployed & $64(16.7)$ \\
\hline Retiree & $5(1.3)$ \\
\hline Self-employed & $27(7.0)$ \\
\hline Student & $92(24.0)$ \\
\hline \multicolumn{2}{|l|}{ Monthly income } \\
\hline$<1000$ & $54(14.1)$ \\
\hline $1000-3000$ & $116(30.2)$ \\
\hline $3001-5000$ & $54(14.1)$ \\
\hline $5001-10000$ & $25(6.5)$ \\
\hline$>10000$ & $7(1.8)$ \\
\hline None & 128 (33.3) \\
\hline
\end{tabular}

A total of $119(31.0 \%)$ women attended their respective places of worship a few times a year, followed by a few times a month $(89,23.2 \%)$. Ninety-four $(24.5 \%)$ women were involved in private religious activities (e.g. prayer, meditation, or reading the 'Al-Quran' or 'Bible') daily. Eighty-nine $(23.2 \%)$ women rarely or never engaged in such private religious activities in their lives.

\section{Religiosity and knowledge of breast cancer}

A total of 176 respondents ( $45.8 \%$ ) obtained a moderate score of knowledge on breast cancer, with a total median knowledge score of 12.50 . Most of the respondents demonstrated limited 
knowledge of breast cancer's risk factors, with a median score of 4.00 out of 10.00 . However, knowledge of symptoms of breast cancer was good, with a median score of 6.00 out of 8.00 . Details of respondents' breast cancer knowledge are shown in Table 3.

All subscales of religiosity were studied to evaluate the association between religiosity and knowledge of breast cancer. There was no significant association between ORA and knowledge of breast cancer (ORA: $r=-0.007, p>$ 0.05). However, NORA and IR were significantly negatively correlated with knowledge of breast cancer (NORA: $r=-0.113, p<0.05$; IR: $r=-$ 0183, $p<0.01)$.

\section{Religiosity and perceptions of breast cancer and its treatment}

More than two thirds of respondents agreed that patients undergoing treatment of breast cancer could enjoy good quality of life $(81.3 \%)$ without embarrassment (76.8 \%). About half of the respondents agreed that breast cancer treatment is a long and painful process (54.9\%), though it did not result in loss of physical beauty (51.6\%). Table 4 summarises respondents' responses on perceptions of breast cancer and its treatment.

Table 4 shows the associations between religiosity and perceptions of breast cancer and its treatment. ORA was not significantly correlated with any perception of breast cancer and its treatment. However, NORA and IR were positively, significantly correlated with the perception that a woman can enjoy good quality of life after receiving treatment for breast cancer (NORA: $r=0.115, p<0.05$; IR: $r=0.228, p<$ $0.01)$. NORA and IR also showed a positive significant correlation with the perception that spiritual support improves treatment of breast cancer (NORA: $r=0.175, p<0.05$; IR: $r=0.249$, $p<0.01)$. Moreover, IR was positively significant-

Table 3: Knowledge of breast cancer among respondents

\begin{tabular}{|c|c|c|c|c|}
\hline Item & Range & Median (IQR) & $\begin{array}{l}\text { Correct, } \\
\mathrm{n}(\%)\end{array}$ & $\begin{array}{l}\text { Incorrect, } \\
\mathrm{n}(\%)\end{array}$ \\
\hline General knowledge & $1-4$ & $2.00(1.00)$ & & \\
\hline $\begin{array}{l}\text { Only females are affected by breast } \\
\text { cancer }\end{array}$ & & & $263(68.5)$ & $121(31.5)$ \\
\hline $\begin{array}{l}\text { Breast cancer can be transmitted from one } \\
\text { person to another }\end{array}$ & & & $316(82.3)$ & $68(17.7)$ \\
\hline $\begin{array}{l}\text { Breast cancer is the leading cause of } \\
\text { death in Malaysian women }\end{array}$ & & & $86(22.4)$ & $298(77.6)$ \\
\hline $\begin{array}{l}\text { The estimated life time risk of developing } \\
\text { breast cancer in Malaysian women is } 1 \text { in } \\
19\end{array}$ & & & $151(39.3)$ & $233(60.7)$ \\
\hline Knowledge of breast cancer risk factors & $1-10$ & $4.00(3.00)$ & & \\
\hline Old age & & & $169(44.0)$ & $215(56.0)$ \\
\hline Family history of breast cancer & & & $301(78.4)$ & $83(21.6)$ \\
\hline Cigarette smoking & & & $183(47.7)$ & $201(52.3)$ \\
\hline Low-fat diet & & & $243(63.3)$ & $141(36.7)$ \\
\hline First child after the age of 30 years & & & $131(34.1)$ & $253(65.9)$ \\
\hline $\begin{array}{l}\text { Early onset of menses (before the age of } \\
12 \text { years) }\end{array}$ & & & $131(34.1)$ & $253(65.9)$ \\
\hline $\begin{array}{l}\text { Late menopause (after the age of } 55 \\
\text { years) }\end{array}$ & & & $128(33.3)$ & $256(66.7)$ \\
\hline Use of oral contraceptive & & & $115(29.9)$ & $269(70.1)$ \\
\hline Large breast & & & $105(27.3)$ & $279(72.7)$ \\
\hline Breastfeeding & & & $252(65.6)$ & $132(34.4)$ \\
\hline Knowledge of breast cancer symptoms & $1-8$ & $6.00(3.00)$ & & \\
\hline Painless breast lump & & & $223(58.1)$ & $161(41.9)$ \\
\hline Lump under armpit & & & $265(69.0)$ & $119(31.0)$ \\
\hline Nipple discharge (excluding milk) & & & $253(65.9)$ & $131(34.1)$ \\
\hline Change in breast shape & & & $299(77.9)$ & $85(22.1)$ \\
\hline Pain in breast region & & & $318(82.8)$ & $66(17.2)$ \\
\hline Dimpling of breast skin & & & $195(50.8)$ & $189(49.2)$ \\
\hline $\begin{array}{l}\text { BSE (breast self-examination) is } \\
\text { recommended for females once a month }\end{array}$ & & & $297(77.3)$ & $87(22.7)$ \\
\hline $\begin{array}{l}\text { CBE (clinical breast examination) is } \\
\text { recommended for females once a year }\end{array}$ & & & $295(76.8)$ & $89(23.2)$ \\
\hline Total knowledge score & $0-22$ & $12.50(5.00)$ & \multicolumn{2}{|c|}{ Moderate knowledge } \\
\hline
\end{tabular}


Table 4: Perceptions of breast cancer and its treatment, as well as its association with religiosity

\begin{tabular}{|c|c|c|c|c|c|c|c|c|}
\hline \multirow[t]{2}{*}{ Perception } & \multirow[b]{2}{*}{$S A$} & \multirow[b]{2}{*}{$\boldsymbol{A}$} & \multirow[b]{2}{*}{$N$} & \multirow[b]{2}{*}{$D A$} & \multirow[b]{2}{*}{$S D A$} & \multicolumn{3}{|c|}{ Religiosity $(P \text {-value })^{\mathrm{a}}$} \\
\hline & & & & & & ORA & NORA & IR \\
\hline $\begin{array}{l}\text { A woman after receiving treatment for breast cancer can } \\
\text { enjoy a good quality of life }\end{array}$ & $\begin{array}{c}137 \\
(35.7)\end{array}$ & $\begin{array}{c}175 \\
(45.6)\end{array}$ & $\begin{array}{c}52 \\
(13.5)\end{array}$ & $\begin{array}{c}19 \\
(4.9)\end{array}$ & $\begin{array}{c}1 \\
(3)\end{array}$ & $\begin{array}{c}0.037 \\
(0.471)\end{array}$ & $\begin{array}{l}0.115^{\star} \\
(0.024)\end{array}$ & $\begin{array}{l}0.229^{\star *} \\
(0.000)\end{array}$ \\
\hline Treatment for breast cancer is a long and painful process & $\begin{array}{c}52 \\
(13.5)\end{array}$ & $\begin{array}{c}159 \\
(41.4)\end{array}$ & $\begin{array}{c}113 \\
(29.4)\end{array}$ & $\begin{array}{c}55 \\
(14.3)\end{array}$ & $\begin{array}{c}5 \\
(1.3)\end{array}$ & $\begin{array}{l}-0.007 \\
(0.888)\end{array}$ & $\begin{array}{l}0.010 \\
(0.841)\end{array}$ & $\begin{array}{l}-0.023 \\
(0.650)\end{array}$ \\
\hline $\begin{array}{l}\text { Treatment for breast cancer are more helpful to young } \\
\text { people }\end{array}$ & $\begin{array}{c}62 \\
(16.1)\end{array}$ & $\begin{array}{c}137 \\
(35.7)\end{array}$ & $\begin{array}{c}117 \\
(30.5)\end{array}$ & $\begin{array}{c}57 \\
(14.8)\end{array}$ & $\begin{array}{c}11 \\
(2.9)\end{array}$ & $\begin{array}{c}0.053 \\
(0.299)\end{array}$ & $\begin{array}{c}0.067 \\
(0.193)\end{array}$ & $\begin{array}{l}0.152^{* *} \\
(0.003)\end{array}$ \\
\hline Treatment for breast cancer is embarrassing & $\begin{array}{c}15 \\
(3.9)\end{array}$ & $\begin{array}{c}22 \\
(5.7)\end{array}$ & $\begin{array}{c}52 \\
(13.5)\end{array}$ & $\begin{array}{c}144 \\
(37.5)\end{array}$ & $\begin{array}{c}151 \\
(39.3)\end{array}$ & $\begin{array}{c}0.003 \\
(0.949)\end{array}$ & $\begin{array}{c}0.073 \\
(0.156)\end{array}$ & $\begin{array}{l}0.083 \\
(0.104)\end{array}$ \\
\hline $\begin{array}{l}\text { Treatment of breast cancer results in loss of physical } \\
\text { beauty }\end{array}$ & $\begin{array}{l}25 \\
(6.5)\end{array}$ & $\begin{array}{c}89 \\
(23.2)\end{array}$ & $\begin{array}{c}72 \\
(18.8)\end{array}$ & $\begin{array}{c}140 \\
(36.5)\end{array}$ & $\begin{array}{c}58 \\
(15.1)\end{array}$ & $\begin{array}{l}-0.044 \\
(0.389)\end{array}$ & $\begin{array}{l}-0.043 \\
(0.400)\end{array}$ & $\begin{array}{l}-0.129 \\
(0.011)\end{array}$ \\
\hline $\begin{array}{l}\text { Total breast removal is a better primary treatment choice } \\
\text { than breast conserving surgery }\end{array}$ & $\begin{array}{c}39 \\
(10.2)\end{array}$ & $\begin{array}{c}129 \\
(33.6)\end{array}$ & $\begin{array}{c}121 \\
(31.5)\end{array}$ & $\begin{array}{c}72 \\
(18.8)\end{array}$ & $\begin{array}{l}23 \\
(6.0)\end{array}$ & $\begin{array}{c}-0.054 \\
(0.290)\end{array}$ & $\begin{array}{c}-0.064 \\
(0.213)\end{array}$ & $\begin{array}{l}-0.111^{*} \\
(0.030)\end{array}$ \\
\hline $\begin{array}{l}\text { Macrobiotics, megavitamins or other dietary supplements } \\
\text { are good alternative medicine for treatment of breast } \\
\text { cancer }\end{array}$ & $\begin{array}{c}28 \\
(7.3)\end{array}$ & $\begin{array}{c}138 \\
(35.9)\end{array}$ & $\begin{array}{c}139 \\
(36.2)\end{array}$ & $\begin{array}{c}70 \\
(18.2)\end{array}$ & $\begin{array}{c}9 \\
(2.3)\end{array}$ & $\begin{array}{c}0.001 \\
(0.982)\end{array}$ & $\begin{array}{c}0.067 \\
(0.189)\end{array}$ & $\begin{array}{c}0.126^{*} \\
(0.014)\end{array}$ \\
\hline Treatment of breast cancer using acupuncture is useful & $\begin{array}{c}22 \\
(5.7)\end{array}$ & $\begin{array}{c}62 \\
(16.1)\end{array}$ & $\begin{array}{c}173 \\
(45.1)\end{array}$ & $\begin{array}{c}106 \\
(27.6)\end{array}$ & $\begin{array}{c}21 \\
(5.5)\end{array}$ & $\begin{array}{l}-0.060 \\
(0.242)\end{array}$ & $\begin{array}{c}0.049 \\
(0.339)\end{array}$ & $\begin{array}{l}0.120^{*} \\
(0.018)\end{array}$ \\
\hline $\begin{array}{l}\text { Spiritual support helps in improving treatment of breast } \\
\text { cancer }\end{array}$ & $\begin{array}{c}153 \\
(39.8)\end{array}$ & $\begin{array}{c}148 \\
(38.5)\end{array}$ & $\begin{array}{c}60 \\
(15.6)\end{array}$ & $\begin{array}{c}20 \\
(5.2)\end{array}$ & $\begin{array}{c}3 \\
(0.8)\end{array}$ & $\begin{array}{c}0.091 \\
(0.076)\end{array}$ & $\begin{array}{l}0.175^{\star *} \\
(0.001)\end{array}$ & $\begin{array}{l}0.249^{* *} \\
(0.000)\end{array}$ \\
\hline
\end{tabular}


ly correlated with the perception that treatment of breast cancer is more helpful to young people $(r$ $=0.152, p<0.05)$. A positive significant correlation was found between IR and the perception that macrobiotics, megavitamins, or other dietary supplements are good alternative medicines for breast cancer treatment $(r=0.126$, $p<0.05$ ), and with the usage of acupuncture in treatment of breast cancer $(r=0.120, p<0.05)$. On the other hand, a negative significant correlation was found between IR and the perception that total breast removal is a better choice than breast conserving surgery $(r=$ $0.111, p<0.05)$.

\section{DISCUSSION}

Women with frequent private religious activities had significantly poorer knowledge of breast cancer in the present study. Perhaps they spend most of their time reading their respective religious materials (e.g., the Al-Quran or Bible) and allocate less time to searching for medical health information. Thus, they are less likely to learn and read information concerning breast cancer. Women with stronger intrinsic religiosity also had significantly poorer knowledge of breast cancer. Women with higher intrinsic religiosity believe that everything that occurred in their lives is attributable to their god. They may treat their god as the protector who will guide and keep them alive [15]. Additionally, the fatalistic beliefs of women that stressful events such as breast cancer were 'fated' and unavoidable may also result in the refusal to seek any knowledge and treatment about their illness [16].

Women with higher scores on NORA perceived that women could enjoy good quality of life after receiving breast cancer treatment. This may be explained by the fact that frequent practice of private religious activities such as prayer or meditation can foster a sense of control over stressful events through attainment of a faithful relationship with a god who provides guidance and support for them [17]. Further, people with strong religious beliefs or coping may experience improved emotional states such as happiness, compassion, and hope when dealing with stress; thus, they are bound to enjoy good quality of life after breast cancer treatment [4].

Women with higher scores on IR perceived that women could enjoy good quality of life after receiving breast cancer treatment. They believed that a positive religious belief can improve quality of life among patients with advanced diseases such as cancer [18]. Someone with higher levels of religiosity tends to perceive his or her disease less negatively and generally has good quality of life along with treatment [7]. A study by Koenig et al also found that depressive symptoms diminished faster among depressed patients with higher intrinsic religiosity [19].

Women with higher scores on NORA and IR also tend to agree more that spiritual support improves breast cancer treatment. In fact, studies have shown that spirituality and religiosity were positive health mediators for the achievement of better health outcomes [20]. Women undertaking frequent acts of prayer or meditation or higher personal religious commitment will build a stronger relationship with a god or a higher power. They may feel less depressed and accept events from a spiritual perspective as a means of coping with breast cancer. Further, patients with greater spirituality will have better immune defences during treatment [21]. This is because depression and stress may increase levels of adrenal stress hormones that negatively affect immune function [22].

Spiritual support is linked to calmness and improves breast cancer treatment [15]. Another study also showed that spiritual support was associated with patients' peace of mind through the nurturing of their relationship with their god, as well as better quality of life [23]. Adolescents with severe illness, including cancer have heightened spirituality and spiritual coping strategies to manage their illness [24]. This is similar to the present study's results that women with higher intrinsic religiosity perceived breast cancer treatment as more helpful to young people. A study by Ganz et al also showed that overall physical functioning and quality of life among younger breast cancer patients after breast treatment were better than in older patients [25].

Women with higher intrinsic religiosity tended to reject the perception that total breast removal is a better choice of primary treatment for breast cancer than breast conserving surgery is. This could be explained by the fact that highly religious women believe that their god made their body, mind, and soul. Hence, they would not intend to remove a whole breast as a primary treatment choice. Studies have shown no significant differences between the two types of surgical treatments for early breast cancer in terms of overall survival rate [26].

Women with higher intrinsic religiosity tended to agree with the use of dietary therapies as alternative treatments for breast cancer. Those with higher religiosity may choose spiritual recovery instead of conventional treatment; 
hence they may be more receptive toward dietary treatment (e.g. megavitamins and macrobiotics) alongside divine healing. However, according to Cancer Research UK, to date, there is no evidence on the curability of cancer through alternative therapies. In fact, dietary therapies could lead to harmful side effects that may influence the efficacy of conventional medical treatment [27].

Women with higher intrinsic religiosity also tended to agree that acupuncture therapy is useful as an alternative treatment for breast cancer. They trusted that traditional therapy such as acupuncture was a more 'natural' approach and compatible with their religious philosophy [28]. This was further supported by their disagreement with conventional treatment due to its adverse effects [29]. To date, there is no evidence that acupuncture therapy can cure cancer. However, acupuncture showed beneficial effects with regard to relieving cancer-related fatigue [30] and hot flushes caused by antiestrogenic drugs among breast cancer patients [31].

\section{Limitations of the study}

The convenience sampling method might have introduced selection bias, as highly motivated respondents were more likely to participate in the study, compared to others. The results obtained may not be generalised to the whole Malaysian population, as the study was mainly conducted in Kuala Lumpur. Furthermore, other factors related to religion, such as social support or stress coping, that could have influenced the knowledge and perception of breast cancer and its treatment were not investigated in the present study.

\section{CONCLUSION}

Women around the Kuala Lumpur area demonstrate moderate knowledge of breast cancer. There are significant negative correlations between knowledge of breast cancer and aspects of NORA and IR. Women with higher NORA and IR scores agree that women receiving treatment for breast cancer enjoy good quality of life. They also agree that spiritual support improves treatment for breast cancer. IR is the only subscale that positively correlate with the perception of breast-conserving surgery as a primary treatment choice and dietary therapies or acupuncture as alternative treatments for breast cancer. Women with higher IR scores also agree that breast cancer treatment is more helpful to young people. Addressing religiosity is crucial when designing interventions to improve knowledge and perceptions regarding breast cancer and its treatment in the general public.

\section{DECLARATIONS}

\section{Acknowledgement}

The authors would like to thank the respondents for completing the questionnaire. This research was funded by the local university (UKM) grant (Grant code: KOMUNITI-2014-009).

\section{Conflict of Interest}

No conflict of interest associated with this work.

\section{Contribution of Authors}

The authors declare that this work was done by the authors named in this article and all liabilities pertaining to claims relating to the content of this article will be borne by them.

\section{Open Access}

This is an Open Access article that uses a funding model which does not charge readers or their institutions for access and distributed under the terms of the Creative Commons Attribution License (http://creativecommons.org/licenses/by/ 4.0) and the Budapest Open Access Initiative (http://www.budapestopenaccessinitiative.org/rea d), which permit unrestricted use, distribution, and reproduction in any medium, provided the original work is properly credited.

\section{REFERENCES}

1. Ferlay J, Soerjomataram I, Dikshit, R, Eser S, Mathers $C$, Rebelo M, Parkin DM, Forman D, Bray F. Cancer incidence and mortality worldwide: sources, methods and major patterns in GLOBOCAN 2012. Int J Cancer 2015; 136: 359-386.

2. Youlden DR, Cramb SM, Yip CH, Baade PD. Incidence and mortality of female breast cancer in the Asia-Pacific region. Cancer Biol Med 2014; 11: 101-15.

3. Hisham AN, Yip $\mathrm{CH}$. Overview of breast cancer in Malaysian women: A problem with late diagnosis. Asian J Surg 2004; 27: 130-132.

4. Koenig HG, King DE, Carson VB. Handbook of Religion and Health, ed 2. Oxford University Press, United States, 2012.

5. Lopez ME. The association of religiosity and use of breast cancer screening among older women in Latin America and the Carribean. UNTHSC Scholarly Repository 2009; 1-55.

6. Plante TG, Sherman AC. Research on Faith and Health: New approaches to old questions. New York: Guilford, 2001. 
7. Patel SS, Shah VS, Peterson RA, Kimmel PL. Psychosocial variables, quality of life, and religious beliefs in ESRD patients treated with hemodialysis. Am J Kidney Dis 2002; 40: 1013-1022.

8. Aukst-Margetić B, Jakovljević M, Margetić B, Bisćan M, Samija M. Religiosity, depression and pain in patients with breast cancer. Gen Hosp Psychiatry 2005; 27: 250255.

9. Akhtari-Zavare $M$, Juni $M H$, Manaf RA, Ismail IR, $M d$ Said S. Knowledge on breast cancer and practice of breast self-examination among selected female university students in Malaysia. Med Health Sci J 2011; 7: 49-56.

10. Hadi MA, Hassali MA, Shafie AA, Awaisu A. Evaluation of breast cancer awareness among female university students in Malaysia. Pharmacy Pract 2010; 8: 29-34.

11. Hadi MA, Hassali MA, Shafie AA, Awaisu A. Knowledge and perception of breast cancer among women of various ethnic groups in the state of Penang: a crosssectional study. Med Princ Pract 2008; 19: 61-67.

12. WMA Declaration of Helsinki - Ethical Principles for Medical Research Involving Human Subjects [cited 2017 Feb 13]. Available from: http://www.wma.net/en/30publications/10policies/b3/

13. Koenig HG, Bussing A: The Duke University Religion Index (DUREL): a five-item measure for use in epidemiological studies. Relig 2010; 1: 78-85.

14. Nurashikin MS, Aini A, Aida SAA, Ng CG. Validity and reliability of the Malay version of Duke University Religion Index (DUREL-M) among a group of nursing student. Malaysian Journal of Psychiatry 2010; 19: 1-5.

15. Choumanova I, Wanat S, Barrett R, Koopman C. Religion and spirituality in coping with breast cancer: perspectives of Chilean women. Breast $J$ 2006; 12 : 349-352.

16. Powe BD, Finnie R. Cancer fatalism. Cancer Nurs 2003; 26: 454-467.

17. Dull VT, Skokan LA. A cognitive model of religion's influence on health. J Soc Iss 1995; 51: 49-64.

18. Tarakeshwar N, Vanderwerker LC, Paulk E, Pearce MJ, KasI SV, Prigerson HG. Religious coping is associated with the quality of life of patients with advanced cancer. J Palliat Med 2006; 9: 646-657.

19. Koenig HG, George LK, Peterson BL. Religiosity and remission of depression in medically ill older patients. Am J Psychiatry 1998; 155: 536-542.
20. Nelson C, Jacobson CM, Weinberger MI, Bhaskaran V, Rosenfeld B, Breitbart W, Roth AJ. The role of spirituality in the relationship between religiosity and depression in prostate cancer patients. Ann Behav Med 2009; 38: 105-114.

21. Sephton SE, Koopman C, Schaal M, Thoresen C, Spiegel D. Spiritual expression and immune status in women with metastatic breast cancer: an exploratory study. Breast J 2001; 7: 345-353.

22. Reiche EMV, Nunes SOV, Morimoto HK. Stress, depression, the immune system, and cancer. Lancet Oncol 2004; 5: 617-625.

23. Balboni TA, Vanderweker LC, Block SD, Paulk ME, Lathan CS, Peteet JR, Prigerson HG. Religiousness and spiritual support among advanced cancer patients and associations with end-of-life treatment preferences and quality of life. J Clin Oncol 2007; 25: 555-560.

24. Cotton S, Zebracki K, Rosenthal SL, Tsevat J, Drotar D. Religion/spirituality and adolescent health outcomes: a review. J Adolesc Health 2006; 38: 472-480.

25. Ganz PA, Greendale GA, Petersen L, Kahn B, Bower JE. Breast cancer in younger women: reproductive and late health effects of treatment. J Clin Oncol 2003; 21: 4184-4193.

26. Poggi MM, Danforth DN, Sciuto LC, Smith SL, Steinberg $S M$, Liewehr DJ, Menard C, Lippman ME, Lichter AS, Altemus RM. Eighteen-year results in the treatment of early breast carcinoma with mastectomy versus breast conservation therapy: The National Cancer Institute Randomized Trial. Cancer 2003: 98: 697-702.

27. Markman M. Safety issues in using complementary and alternative medicine. J Clin Oncol 2002; 20: 39-41.

28. Charlton BG. The doctor's aim in a pleuralistic society: a response to 'healing and medicine'. J R Soc Med 1993; 86: 125-126.

29. Bass PF. Alternative medicine for atopic dermatitis. Contemp Pediatr 2014; 1-7.

30. Molassiotis A, Bardy J, Finnegan-John J, Mackereth P, Ryder DW, Filshie J, Ream $E$, Richardson $A$. Acupuncture for cancer-related fatigue in patients with breast cancer: a pragmatic randomized controlled trial. J Clin Oncol 2012; 4470-4476.

31. Hervik J, Mjaland O. Acupuncture for the treatment of hot flashes in breast cancer patients, a randomized, controlled trial. Breast Cancer Res Treat 2009; 116: 311-316. 